\title{
PELEPASAN HAK ATAS TANAH BAGI PEMBANGUNAN UNTUK KEPENTINGAN UMUM PT. BALI PECATU GRAHA (Studi Kasus Perkara Nomor: 65K/pdt/2012/MA)
}

\author{
Wayan Artana, A. Agung Sagung Laksmi Dewi, Luh Putu Suryani \\ Fakultas Hukum Universitas Warmadewa Denpasa-Bali, Indonesia \\ artanawayan92@gmail.com, laksmiidewi29@gmail, computusuryani099@gmail.com
}

\begin{abstract}
Abstrak
Saat ini konflik pertanahan yang terjadi umumnya disebabkan oleh benturan kepentingan dengan peraturan perundang-undangan yang berlaku dan seringkali ganti rugi yang tidak sesuai. Penelitian ini bertujuan untuk mengkaji pengaturan hukum pelepasan hak atas tanah untuk pembangunan untuk kepentingan umum di Indonesia yang mengacu pada Undang-undang Nomor 2 Tahun 2012 dan mengungkap perlindungan hukum pelepasan hak atas tanah untuk pembangunan untuk kepentingan umum PT. Bali Pecatu Graha. Metode penelitian yang digunakan adalah deskriptif-analitis dengan pendekatan yuridis normatif dan analisis yuridis kualitatif. Data yang digunakan adalah data hukum primer dan sekunder yang diperoleh melalui teknik sistem kartu. Hasil penelitian menunjukkan bahwa pelepasan tanah mengacu pada UU No. 2 Tahun 2012 dan UU No. 5 Tahun 1960. Perlindungan hukum bagi PT. Bali Pecatu Graha karena perbuatan pelepasan hak atas tanah harus memperoleh kepastian hukum pelepasan hak atas tanah dan memerlukan tersedianya perangkat hukum yang tertulis, lengkap dan jelas yang dilakukan secara konsisten sesuai dengan semangat dan isi ketentuan, sehingga kepentingan pribadi mendapat perlindungan hukum yang optimal.
\end{abstract}

Kata kunci: Pelepasan Hak, Perlindungan Hukum, Pembangunan

\begin{abstract}
Currently, land conflicts that occur are generally caused by conflicts of interest with applicable laws and regulations and often inappropriate compensation. This study aimed to examine the legal arrangements for relinquishing land rights for development in the public interest in Indonesia which refers to Law Number 2 of 2012 and uncover legal protections for relinquishing land rights for development in the public interest of PT. Bali Pecatu Graha. The research method used was descriptive-analytical with a normative juridical approach and qualitative juridical analysis. The data used were primary and secondary legal data obtained through card system techniques. The results of the study indicated that the release of the land refers to Law no. 2 of 2012 and Law no. 5 of 1960. Legal protection for PT. Bali Pecatu Graha due to the act of relinquishing land rights must obtain legal certainty of relinquishment of land rights and requires the availability of written, complete and clear legal instruments that are carried out consistently in accordance with the spirit and content of the provisions so that personal interests get optimal legal protection.
\end{abstract}

Keywords: Release of Rights, Legal Protection, Development

\section{PENDAHULUAN}

Tanah merupakan kebutuhan dasar manusia. Hak bangsa Indonesia atas tanah merupakan hak penguasaan tanah yang tertinggi dan meliputi semua tanah yang ada dalam wilayah negara, yang merupakan tanah bersama, bersifat abadi, dan menjadi induk bagi hak penguasa yang lain atas tanah (Santoso, 2015:16). Kasenda (2015) Pemerintah mempunyai kewajiban menyediakan tanah yang diperlukan untuk pembangunan, antara lain dari tanah negara yang tidak dikuasai oleh rakyat ataupun dengan menyediakan bank tanah bagi kepentingan pembangunan. Secara konstitusional Undangundang Dasar Negara Republik Indonesia tahun 1945 dalam Pasal 33 ayat (3) telah memberikan landasan bahwa Bumi dan air serta kekayaan alam yang terkandung di dalamnya dikuasai oleh negara dan dipergunakan sebesar-besar untuk kemakmuran rakyat.

Wangke (2016) Pada saat sekarang ini konflik pertanahan yang terjadi pada umumnya banyak terdapat pada proses mekanisme pembebasan tanah untuk kepentingan umum yang tidak sesuai dengan peraturan perundangan yang berlaku serta ganti kerugian yang sering tidak sesuai dengan apa yang diwujudkan oleh pemerintah sehingga menimbulkan konflik ditengah masyarakat. 
Dengan diundangkannya Undang-undang Nomor 2 Tahun 2012 tentang Pengadaan Tanah Bagi Pembangunan Untuk Kepentingan Umum. Pengadaan tanah dalam pelaksanaan pembangunan untuk kepentingan umum oleh pihak swasta, selain dapat dilaksanakan dengan cara jual-beli, tukar menukar, dapat dilakukan dengan cara lain yang disepakati secara sukarela oleh pihak-pihak yang bersangkutan. Dalam pembangunan sekarang pembebasan tanah dan pencabutan hak atas tanah adalah merupakan sarana yang terpenting untuk mendapatkan tanah untuk keperluan pembangunan. Tanah-tanah yang ada saat ini banyak yang dikuasai perseorangan baik melalui kepemilikan yang sah, atau karena adanya penyerobotan tanah yang kemudian memunculkan permasalahan-permasalahan hukum, atau gugatan hukum dari pemilik yang sah.

Dalam hal Kasus perkara antara PT. Bali Pecatu Graha dengan I Wayan Bendi, I Made Ganti, I Nyoman Kicen dan Hari Boedihartono dalam putusan Mahkamah Agung Nomor 65K/PDT/2012, Dalam perkara tersebut PT. Bali Pecatu Graha telah melaksanakan perjanjian pelepasan dan pembebasan hak atas tanah dengan I Nyoman Raneng. Tanah dengan Sertifikat Hak Milik Nomor 3023/Desa Jimbaran atas nama I Nyoman Raneng seluas $10.800 \mathrm{M}^{2}$ (sepuluh ribu delapan ratus meter persegi) yang terletak di Desa Jimbaran, Kecamatan Kuta Selatan, Kabupaten Badung. Tanah tersebut merupakan pemisahan dan pembagian dari hak milik, pipil nomor 636, persil nomor 21, klas VI, luas seluruhnya $19.800 \mathrm{M}^{2}$ (sembilan belas ribu delapan ratus meter persegi) atas nama Pan Sukera, berdasarkan Akta Pemisahan dan Pembagian Nomor: 5/KUTA/1995 tanggal 25 Maret 1995 yang dibuat oleh I Gusti Ngurah Putra Wijaya, Notaris di Denpasar selaku Pejabat Pembuat Akta Tanah. Batas tanah-tanah tersebut adalah Utara berbatas dengan Tanah milik I Rangkeng (Kini milik PT. Bali Pecatu Graha), timur adalah Tanah negara dan tanah milik I Surat (Kini milik PT. Bali Pecatu Graha), Selatan: adalah Tanah Milik Pan Sukera (Kini milik PT. Bali Pecatu Graha) dan Barat adalah Tanah milik I Wayan Sukara.

Dikutip dari gelar perkara kasus, "Terhadap tanah seluas $10.800 \mathrm{M}^{2}$ yang menjadi tanah sengketa antara PT. Bali Pecatu Graha dengan I Wayan Bendi, para pihak mengkalim mempunyai atas hak kepemilikan. I Wayan Bendi mengklaim memiliki dan menguasai tanah sengketa dengan dasar bahwa tanah sengketa tersebut merupakan hak waris yang didapatkannya dari I Nyoman Raneng. Dalam sistem kekeluargaan yang bersifat patrilinial seperti halnya kekeluargaan menurut hukum adat Bali, harta yang diperoleh seorang suami didalam perkawinan sebagai pembagian warisan dari orang tuanya tidak jatuh menjadi harta bersama dengan isterinya (gono-gini) melainkan tetap menjadi hak atau milik suami, Maka dalam hal kemudian si isteri meninggal lebih dahulu dari suaminya ia tidak mewariskan harta tersebut di atas kepada anak-anaknya. PT. Bali Pecatu Graha mengklaim memiliki dan menguasai tanah sengketa dengan dasar Akta Perjanjian Akan Melepaskan dan Membebaskan Hak Atas Tanah Nomor 26 Tanggal 26 Mei 1995. Perjanjian tersebut dituangkan dalam bentuk akta otentik yang dibuat di hadapan I Ketut Purna, Notaris di Denpasar antara I Nyoman Raneng dengan PT. Bali Pecatu Graha yang diwakili oleh Made Gede Putrawan selaku Direktur Perseroan Terbatas. Bahwa I Nyoman Reneng telah menyerahkan tanah sengketa kepada PT. Bali Pecatu Graha (Pemohon Kasasi) yang dibuktikan pembayaran dan penerimaan uang sebesar Rp 216.000.000,00 (dua ratus enam belas juta rupiah), seperti Berdasarkan kepada akta tersebut PT. Bali Pecatu Graha telah memiliki kuasa untuk memiliki hak atas tanah tersebut yang tercantum di dalam kwitansi tertanggal 22 Mei 1995.

Penelitian terdahulu yang relevan dengan penelitian ini dilakukan oleh Meriasti \& Resen, (2021) mengungkapkan proses pengadaan tanah tersebut pemerintah tidak bisa semena-mena menyangkut tanah hak masyarakat tanpa prosedur dan mekanisme sebagai mana ketentuan hukum yang berlaku sesuai yang diatur dalam Undang-undang No. 2 Tahun 2012. Penyebabnya macetnya pemberian ganti rugi yaitu sosialisasi terdapat kesalahan Detail Engineering Design dan jangka waktu sosialisasi mengalami keterlambatan, selanjutnya pada musyawarah penetapan ganti kerugian, pihak pemilik tanah tidak diberikan kesempatan untuk mengemukakan pendapat dalam menentukan besarnya ganti kerugian (Adhim, 2019); (Motulo, 2018). Walaupun sudah banyak penelitian terkait pelepasa hak atas tanah, namun sampai saat ini masih solusi yang tepat untuk mengatasi permasalhan ini. Dari fenomena ini ingin melakukan penelitian dari penyajian yang berbeda dari penelitian sebelumnya dengan tujuan bertujuan mengkaji pengaturan hukum pelepasan terhadap hak tanah bagi pembangunan demi kepentingan umum di Indonesia mengacu pada Undang-undang Nomor 2 Tahun 
2012 dan mengungungkapkan Perlindungan hukum bagi pelepasan hak atas tanah bagi pembangunan untuk kepentingan umum PT. Bali Pecatu Graha.

\section{METODE PENELITIAN}

Tipe Penelitian ini yaitu penelitian hukum normatif. Dalam penelitian hukum normatif suatu metode penulisan hukum yang berdasarkan pada teori-teori hukum, literatur-literatur hukum, dan peraturan Perundang-undangan. Adapun pendekatan masalah yang digunakan yaituPendekatan perundangundangan (statute approach), pendekatan konseptual (conceptual approach) dan pendekatan kasus (case approach). Teknik pengumpulan bahan hukum yang dipergunakan adalah teknik sistem kartu (card system). Setelah semua bahan-bahan hukum telah terkumpulkan perlu dilakukan suatu analisis secara kulaitatif. Data yang digunakan bersal dari bahan primer hingga bahan sekunder. Data dianlisis secara kulitatif deskriptif.

\section{HASIL DAN PEMBAHASAN}

\section{Pengaturan Hukum tentang Pelepasan Hak Atas Tanah}

Pelepasan hak atas tanah adalah kegiatan melepaskan hubungan hukum antara pemegang hak hak atas tanah dengan tanah yang dikuasainya dengan memeberikan ganti rugi atas dasar musyawarah. Pelepasan tanah ini hanya dapat dilakukan atas dasar persetujuan dan kesepakatan dari pihak pemegang hak baik mengenai teknik pelaksnaannya maupun mengenai besar dan bentuk ganti rugi yang akan diberikan terhadap tanahnya (Ratnawati et al, 2018). Kegiatan pelepasan hak ini bukan hanya dilakukan untuk kepentingan swasta. Mengenai tanah-tanah yang dilepaskan haknya dan mendapat ganti rugi adalah tanah-tanah yang telah mempunyai sesuatu hak berdasarkan Undangundang Nomor 5 Tahun 1960 (UUPA) dan tanah-tanah masyarakat hukum adat. Adapun ganti rugi yang diberikan kepada pihak yang telah melepaskan haknya tersebut adalah dapat berupa uang, tanah pengganti atau pemukiman kembali. Pelepasan hak merupakan kegiatan pengadaan tanah yang menerapkan prinsip penghormatan terhadap tanah.

Dasar hukum pelepasan atas tanah adalah Undang-undang NO. 5 Tahun 1960 UUPA dalam Pasal 18 yang berbunyi Untuk kepentingan umum, termasuk kepentingan bangsa dan negara serta kepentingan bersama dari rakyat, hak-hak atas tanah dapat dicabut, dengan memberi ganti kerugian yang layak dan menurut cara yang diatur dengan Undang-undang. Perpres Nomor 36 Tahun 2005 Pasal 1 angka 3 dijelaskan bahwa Pengadaan tanah adalah setiap kegiatan untuk mendapatkan tanah dengan cara memberikan ganti rugi kepada yang melepaskan atau menyerahkan tanah, bangunan, tanaman dan benda-benda yang berkaitan dengan tanah atau dengan pencabutan hak atas tanah

Pengadaan tanah menurut Perpres Nomor 65 Tahun 2006 selain dengan memberikan ganti kerugian juga dimungkinkan untuk dapat dilakukan dengan cara pelepasan hak. Sementara itu Undang-undang Nomor 2 Tahun 2012 tentang Pengadaan Tanah Bagi Pembangunan Untuk Kepentingan Umum, dalam Pasal 1 angka 2 disebutkan bahwa: "Pengadaan tanah adalah kegiatan menyediakan tanah dengan cara memberi ganti kerugian yang layak dan adil kepada pihak yang berhak dimana pengadaan tanah dibatasi sebagai kegiatan untuk memperoleh tanah dengan cara ganti rugi kepada pihak yang terkena pengadaan tanah untuk kegiatan pembangunan bagi kepentingan umum.

UUPA tetap memberikan prioritas sosial atas tanah yang ditetapkan dalam Pasal 6 yang menyatakan bahwa semua hak atas tanah mempunyai fungsi sosial. Hal ini sejalan dengan alam pikiran hukum adat sebagai dasar pembentukan UUPA. maka berdasarkan Pasal 18 UUPA jika untuk kepentingan umum, termasuk kepentingan bangsa dan negara serta kepentingan bersama dari rakyat, hak-hak atas tanah dapat dicabut. Pencabutan hak atas tanah dasar yuridis pengambilan tanah rakyat melalui mekanisme ini adalah ketentuan Pasal 18 UUPA, yang menyatakan bahwa: Untuk kepentingan umum, termasuk kepentingan bangsa dan negara serta kepentingan bersama dari rakyat, hak-hak atas tanah dapat dicabut, dengan memberi ganti kerugian yang layak dan menurut cara yang diatur dengan undang- undang. Menurut Keppres Nomor 55 Tahun 1993, ada dua macam cara pengadaan tanah, yakni pelepasan atau penyerahan hak atas tanah dan jual beli, tukar menukar dan cara lain yang disepakati oleh para pihak yang bersangkutan.

Perpres Nomor 65 Tahun 2006 jelas bahwa Pengadaan tanah bagi pelaksanaan pembangunan untuk kepentingan umum oleh pemerintah atau pemerintah daerah dilaksanakan dengan cara pelepasan atau penyerahan hak atas tanah atau pencabutan hak atas tanah. Pelaksanaan pengadaan 
tanah bagi pembangunan untuk kepentingan umum berdasarkan Undang-undang Nomor 2 Tahun 2012 hanya dilakukan berdasarkan pelepasan atau penyerahan hak atas tanah. Dalam Pasal 1 angka 9 UU Nomor 2 Tahun 2012 disebutkan bahwa Pelepasan hak adalah kegiatan pemutusan hubungan hukum dari pihak yang berhak kepada negara melalui Lembaga pertanahan.

Sesuai UU Nomor 2 tahun 2012, pengadaan tanah untuk kepentingan umum diselenggarakan melalui tahapan perencanaan, persiapan, pelaksanaan dan penyerahan hasil. Instansi yang memerlukan tanah membuat perencanaan pengadaan tanah untuk kepentingan umum menurut ketentuan peraturan perundang-undangan. Perencanaan pengadaan tanah untuk kepentingan umum didasarkan atas Rencana tata ruang wilayah dan prioritas pembangunan yang tercantum dalam Rencana pembaangunan jangka menengah, rencana strategis, rencana kerja pemerintah instansi yang bersangkutan.

\section{Bentuk Perlindungan Hukum bagi Pihak Penggugat Akibat dari Adanya Perbuatan Melawan Hak atas Tanah}

Aprilianti et al. (2019) Keppres Nomor 55 Tahun 1993, Perpres Nomor 36 Tahun 2005 dan Perpres Nomor 65 Tahun 2006 mengandung banyak kelemahan dan bersifat represif yang merugikan pemilik hak atas tanah. Ada beberapa ketentuan yang menunjukkan semangat represif tersebut yaitu Perhitungan Ganti Rugi dimana Tidak adanya ketentuan bahwa pemberian ganti rugi itu menjamin kehidupan rakyat yang kehilangan hak atas tanahnya jadi lebih baik. Bentuk ganti rugi yang diatur hanya materiil, bahkan standar nilai ganti rugi tanah hanya berdasarkan NJOP, bukan berdasarkan harga pasarl Proses Pengadaan Tanah dimana Jika waktu musyawarah yang ditentukan melewati batas maka pemegang hak atas tanah tidak memiliki pilihan lain, kecuali dipaksa menerima ganti rugi yang ditetapkan. Bahkan, hak pemilik tanah atas tanah dapat dicabut, Panitia Pengadaan Tanah (P2T) dimana P2T yang dibentuk hanya mewakili pemerintah. Panitia pengadaan tanah ini dipastikan tak akan netral dan obyektif dalam bernegosiasi untuk pembebasan lahan. Tak ada jaminan bahwa oknum dalam panitia pengadaan tanah ini bermain mata dengan invenstor yang menyediakan modal untuk pembebasan lahan; serta Pencabutan Hak atas Tanah dimana Rakyat makin dilemahkan dengan kehadiran peraturan yang memberi kewenangan kepada pemerintah untuk mencabut hak rakyat atas tanah. Ketentuan ini sangat represif karena memaksa rakyat menyerahkan tanahnya dengan dalih untuk tidak menghambat pembangunan untuk kepentingan umum.

Kasenda (2015) Beberapa kasus pelepasan hak atas tanah bagi pembangunan untuk kepentingan umum menunjukkan bahwa telah timbul berbagai persoalan dalam pelaksanaannya. Mengingat kelemahan-kelemahan dalam peraturan perundang-undangan terdahulu yang berkaitan dengan pelepasan hak atas tanah bagi pembangunan untuk kepentingan umum, maka dengan lahirnya Undang- undang Nomor 2 Tahun 2012, pemerintah mencoba untuk memperbaiki kekurangan tersebut. Pasal 1 angka 10 UU No, 2 Tahun 2012 memberikan pengertian mengenai ganti kerugian yaitu Penggantian yang layak dan adil kepada pihak yang berhak dalam proses pengadaan tanah.

Hasil pengumuman atau verifikasi dan perbaikan verifikasi ditetapkan oleh Lembaga Pertanahan dan selanjutnya menjadi dasar penentuan pihak yang berhak dalam pemberian ganti kerugian (Santoso 2015). Lembaga pertanahan menetapkan Penilai sesuai dengan peraturan perundang-undangan. Lembaga Pertanahan mengumumkan Penilai yang telah ditetapkan untuk melaksanakan penilaian Objek pengadaan Tanah. Penilai yang ditetapkan wajib bertanggung jawab terhadap penilaian yang telah dilaksanakan. Pelanggaran terhadap kewajiban Penilai dikenakan sanksi adminstratif dan/atau pidana ssuai dengan ketentuan perundang- undangan. Penilaian besarnya nilai ganti krugian oleh pemerintah dilakukan bidang per bidang tanah meliputi: Tanah, Ruang atas tanah dan bawah tanah, Bangunan, Tanaman, Benda yang berkaitan dengan tanah dan Kerugian lain yang dapat dinilai.

Zanuardi (2015) Dengan kerugian lain yang dapat dinilai adalah kerugian non fisik yang dapat disetarakan dengan nilai uang, misalnya kerugian karena kehilangan usaha atau pekerjaan, biaya pemindahan tempat, biaya alih profesi, dan nilai atas properti sisa. Nilai ganti kerugian yang dinilai oleh Penilai, merupakan nilai pada saat pengumuman penetapan lokasi pembangunan untuk Kepentingan Umum. Besarnya nilai ganti kerugian berdasarkan hasil penilaian Penilai, disampaikan kepada Lembaga Pertanahan dengan berita acara. Nilai ganti kerugian berdasarkan hasil Penilai, menjadi dasar musyawarah penetap kerugian. Dalam hal bidang tanah tertentu yang terkena 
Pengadaan Tanah terdapat sisa yang tidak lagi dapat difungsikan sesuai dengan peruntukan dan penggunaannya, Pihak yang berhak dapat meminta penggantian secara utuh atas bidang tanahnya. Yang dimaksud dengan tidak lagi dapat difungsikan adalah bidang tanah yang tidak lagi dapat dipergunakan sesuai dengan peruntukan dan penggunaan semula, misalnya rumah hunian yang terbagi sehingga sebagian lagi tidak dapat digunakan sebagai rumah hunian. Sehubungan dengan hal tersebut, pihak yang menguasai atau memiliki tanah dapat meminta ganti kerugian atas seluruh tanahnya. Pemberian Ganti Kerugian dapat diberikan dalam bentuk Uang, Tanah pengganti, Permukiman kembali, Kepemilikan saham dan Bentuk lain yang disetujui oleh kedua belah pihak.

Dikutip dari Peraturan Pemerintah Republik Indonesia Nomor 19 Tahun 2021 Lembaga Pertanahan melakukan musyawarah dengan pihak yang berhak dalam waktu paling lama 30 (tiga puluh) hari kerja sejak hasil penilaian dari Penilai disampaikan kepada Lembaga Pertahanan untuk menetapkan bentuk dan atau besarnya ganti kerugian. Hasil kesepakatan dalam musyawarah, menjadi dasar pemberian ganti kerugian kepada pihak yang berhak yang dimuat dalam berita acara kesepakatan. Tidak terjadi kesepakatan mengenai bentuk dan atau besarnya ganti kerugian, pihak yang berhak dapat mengajukan keberatan kepada pengadilan paling lama empat belas hari kerja setelah musyawarah penetapan ganti kerugian. Pengadilan negeri memutus bentuk atau besarnya ganti kerugian dalam waktu paling lama tiga puluh hari kerja sejak diterimanya pengajuan keberatan. Sebagai pertimbangan dalam memutus putusan atas besaran ganti kerugian, pihak yang berkepentingan dapat menghadirkan saksi ahli di bidang penilaian untuk didengar pendapatnya sebagai pembanding atas penilaian ganti kerugian. Pihak yang keberatan terhadap putusan pengadilan negeri, dalam waktu paling lama empat belas hari kerja dapat mengajukan kasasi kepada Mahkamah Agung Republik Indonesia. Mahkamah Agung wajib memberikan putusan dalam waktu paling lama tiga puluh hari kerja sejak permohonan kasasi diterima. Putusan pengadilan negeri atau Mahkamah Agung yang telah memperoleh kekuatan hukum tetap menjadi dasar pembayaran ganti kerugian kepada pihak yang mengajukan keberatan. Dalam hal pihak yang berhak menolak bentuk dan atau besarnya ganti kerugian tetapi tidak mengajukan keberatan, karena hukum Pihak yang berhak dianggap menerima bentuk dan besarnya ganti kerugian. Pemberian ganti kerugian atas Objek Pengadaan Tanah diberikan langsung kepada Pihak yang berhak.

Dikutip dari Kasenda (2015) Pemberian ganti kerugian pada prinsipnya harus diserahkan langsung kepada pihak yang berhak atas ganti kerugian. Apabila berhalangan, pihak yang berhak karena hukum dapat memberikan kuasa kepada pihak lain atau ahli waris. Penerima kuasa hanya dapat menerima kuasa dari satu orang yang berhak atas ganti kerugian. Pihak yang berhak adalah Pemegang hak atas tanah; Pemegang hak pengelolaan; Nadzir, untuk tanah wakaf; Pemilik tanah bekas milik adat; Masyarakat hukum adat; Pihak yang menguasai tanah negara dengan itikad baik; Pemegang dasar penguasaan atas tanah, dan Pemilik bangunan, tanaman atau benda lain yang berkaitan dengan tanah."

Perlindungan hukum bagi pihak penggugat, pengugat PT. Bali Pecatu Graha, berkedudukan di Denpasar-Bali, dalam hal ini diwakili oleh Suryatin Lijaya, Nyoman Putra, Ida Bagus Pidada Ngurah Manuaba dan Ni Made Murniatl para Advokat, berkantor di Jalan Hayam Wuruk No. 184 Denpasar, berdasarkan surat kuasa khusus tertanggal 28 Juni 2011. Putusan Mahkamah Agung No.65K/Pdt/2012 Mengabulkan gugatan pengugat Konvensi untuk sebagian: Menyatakan sah perjanjian akan melepaskan dan pembebasan hak atas tanah nomor 26 tanggal 22 mei 1995 yang dibuat di hadapan I Ketut Purna, dahulu notaris di Denpasar antara I Nyoman Raneng dan PT. Bali Pecatu Graha, dan mengikat para pihak yang membuatnya serta sekalian ahliwaris atau yang mendapatkan hak dari padanya serta Menyatakan Penggugat berhak untuk melepaskan hak atas tanah sengketa dan mengajukan permohonan untuk mendapatkan Hak Guna Bangunan atas tanah sengketa berdasarkan atas Perjanjian Akan Melepaskan dan Pembebasan Hak Atas Tanah Nomor 26 tanggal 22 Mei 1995 yang dibuat di hadapan I Ketut Purna, dahulu Notaris di Denpasar.

Salman \& Susanto (2007) dan (Marzuki, 2016), "Teori merupakan suatu sistem disusun dari berbagai abstraksi yang saling berkesinambungan satu sama lainya atau berbagai ide yang memadatkan dan mengorganisasi pengetahuan tentang dunia. Van Apeldoorn memberikan dua perngertian mengenai kepastian hukum, pertama kepastian hukum bearti dapat menentukan hukum apa yang berlaku untuk masalah-masalah yang konkret, kedua masalah-masalah yang konkret telah di atur dalam peraturan perundang-undangan, pihak-pihak berkara sudah dapat mengetahui sejak awal ketentuan-ketentuan yang digunakan dalam sengketa tersebut. Setiawan (2017), Perikatan adalah 
hubungan hukum antara dua pihak di dalam lapangan harta kekayaan, dimana pihak yang satu (kreditur) berhak atas suatu prestasi, dan pihak yang lain (debitur) berkewajiban memenuhi prestasi itu. Sumber perikatan dibagi menjadi dua persetujuan atau perjanjian dan sumber undang-undang, disini perjanjian pasal 1313 kitab undang-undang hukum perdata (KUH Perdata) tertulis atau bisa disebut kontak dilihat dari sumber perjanjian. Istilah akta merupakan terjemahan bahasa belanda yaitu acta dalam bahasa prancis disebut acte, sedangkan dalam bahasa inggris disebut dengan deed, akta adalah surat atau tulisan. Unsur-unsur akta dalam definisinya yaitu pertama surat tanda bukti tertulis dan kedua berisi pernyaataan resmi para pihak maupun di muka dan dihadapan pejabat ketiga pembuatan dan penyusunanya didasarkan pada peraturan perundang-undangan yang berlaku.

Perlindungan hukum bagi pihak tergugat putusan Mahkamah Agung No.65K/Pdt/2012 Menolak Eksepsi, "Tergugat I, I Wayan Bendi, I Made Ganti,I Nyoman Kicen kesemuanya bertempat tinggal di Lingkungan Cenggiling, Kelurahan Jimbaran, Kecamatan Kuta Selatan, Kabupaten Badung; Tergugat II, Hari Boedihartono, bertempat tinggal di Jalan Ambengan Nomor 91, RT.002/RW.003, Kelurahan Tambaksari, Kecamatan Tambaksari, Surabaya; Tergugat III, Kepala Kantor Badan Pertanahan Kabupaten Badung, berkedudukan di Jalan Pudak Nomor 7, Denpasar; Menyatakan perbuatan para tergugat I mengambil Sertifikat Hak Milik Nomor: 3023/Desa Jimbaran atas nama I Nyoman Raneng dan merubah pemegang hak sehingga menjadi atas nama I Wayan Bendi, I Made Ganti, I Nyoman Kicen (Para Tergugat I) dan selanjutnya menjual tanah sengketa kepada Tergugat-II adalah tidak sah dan melanggar hukum (onrechtmatig); Menyatakan tidak sah dan karenanya batal jual-beli atas tanah sengketa antara para tergugat I dan tergugat II berdasarkan atas akta jual-beli nomor: 02/10 tanggal 11 Januari 2010 yang dibuat di hadapan Nyoman Alit Puspadma, selaku notaris dan pejabat pembuat akta tanah untuk wilayah Kabupaten Badung; Menyatakan sertifikat hak milik no. 3023/Desa Jimbaran atas nama para tergugat I dan kemudian berubah atas nama tergugat II, tidak mempunyai kekuatan hukum mengikat, Menyatakan gugatan selebihnya tidak dapat diterima.

\section{SIMPULAN DAN SARAN}

\section{Simpulan}

Pengaturan hukum pelepasan terhadap hak tanah bagi pembangunan demi kepentingan umum di Indonesia mengacu pada Undang-undang Nomor 2 Tahun 2012, Landasan yuridis bagi pengadaan tanah untuk kepentingan umum mengacu pada ketentuan Undang-undang Nomor 5 Tahun 1960 dalam Pasal 18 UUPA dan juga dilakukan dengan bantuan panitia pengadaan tanah serta melalui musyawarah guna mencapai kesepakatan mengenai penyerahan tanahnya dan bentuk serta besarnya imbalan atau ganti kerugian. Perlindungan hukum bagi PT. Bali Pecatu Graha akibat adanya perbuatan pelepasan hak atas tanah harus mendapatkan kepastian hukum pelepasan hak atas tanah serta memerlukan tersedianya perangkat hukum yang tertulis, lengkap dan jelas yang dilaksanakan secara konsisten sesuai dengan jiwa dan isi ketentuan-ketentuannya, agar kepentingan swasta mendapatkan perlindungan hukum secara optimal.

\section{Saran}

Pemerintah hendaknya mensosialisasikan lebih aktif kepada masyarakat terkait tentang pelepasan hak atas tanah bagi pembangunan untuk kepentingan umum. Hal ini untuk menghindari permasalahan terkait dengan adanya pelepasan hak atas tanah, mengingat masih adanya masyarakat yang beranggapan bahwa ganti rugi yang diberikan oleh pelaksana proyek, lebih besar atau terkesan menggunakan kesempatan dengan minta harga yang jauh lebih tinggi. Masyarakat hendaknya juga menyadari akan arti penting pembangunan demi kepentingan umum sehingga proses pelepasan tanah tidak berlarut-larut. Hal ini penting agar dalam proses pelepasan hak atas tanah bagi pembangunan untuk kepentingan umum berjalan lancar.

\section{DAFTAR PUSTAKA}

Adhim, N. (2019). Model Upaya Hukum terhadap Ganti Kerugian dalam Pengadaan Tanah untuk Kepentingan Umum (Studi Kasus Pembangunan Jalan Tambaklorok, Kota Semarang). Journal Gema Keadilan, 6(1), 75-85.

Aprilianti, F., Pujiwati, Y., \& Rubiati, B. (2019). Peran Notaris Dalam Pelepasan Hak Atas Tanah Pada Proses Konsolidasi Tanah Guna Optimalisasi Fungsi Tanah Dikaitkan Dengan Peraturan 
Pertanahan. Acta Diurnal Jurnal Ilmu Hukum Kenotariatan Dan Ke-PPAT-An, 2(2), 226.

Kasenda, D. G. (2015). "Ganti Rugi Dalam Pengadaan Tanah Untuk Kepentingan Umum". Jurnal Sekolah Tinggi Ilmu Hukun Tambun Bungai Palangka Raya, 2(2), 2.

Marzuki, P. M. (2016). “Penelitian Hukum.” Jakarta: Kencana.

Meriasti, N. P. C., \& Resen, M. G. S. K. (2021). Perlindungan Hukum Perbuatan Pelepasan Hak atas Tanah Bagi Pembangunan untuk Kepentingan Umum. Jurnal Kertha Wicara, 10(9), 676-691.

Motulo, N. F. (2018). Kepemilikan Properti Warga Negara Asing di Indonesia Menurut Peraturan Pemerintah Nomor 103 Tahun 2015. Lex Et Societatis, 6(10), 65-74.

Peraturan Pemerintah Republik Indonesia Nomor 19 Tahun 2021. (2021). Peraturan Pemerintah

Republik Indonesia Nomor 19 Tahun 2021 tentang Penyelenggaraan Pengadaan Tanah Bagi Pembangunan Untuk Kepentingan Umum, Lembaran Negara Republik Indonesia Tahun 2021 Nomor 29, Tambahan Lembaran Negara Republik Indonesia Nomor 6631. 086995.

Ratnawati, D. H., Asmaranti, A. D., \& Djauhari. (2018). Pelaksanaan Akta Pelepasan Hak Sebagai Alas Hak Untuk Mengajukan Permohonan Peralihan Dan Perubahan Hak Guna Bangunan Yang Jangka Waktunya Telah Berakhir Di Kabupaten Brebes. Jurnal Akta, 5(1), 247-260.

Salman, O., \& Susanto, A. F. (2007). "Teori Hukum (Mengingat, Mengmpulkan dan Membuka Kembali)." Bandung: Refika Utama.

Santoso, U. (2015). "Perolehan Hak Atas Tanah.” Prenamedia Group.

Setiawan, O. (2017). "Hukum Perikatan." Jakarta : Grafika.

Wangke, T. N. (2016). "Pengadaan Tanah Bagi Pembangunan Untuk Kepentingan Umum Di Indonesia." Jurnal Fakultas Hukum Universitas Sam Ratulangi, 4(4), 2.

Zanuardi, H. O. dan A. (2015). Model Penentuan Komponen Kerugian Non Fisik Dalam Pengadaan Tanah Pembangunan Jalan. Jurnal Sosek Pekerjaan Umum, 7(1), 1-79. 